\title{
NATIONAL HEIGHT SYSTEM TESTING USING GNSS MEASUREMENTS IN LATVIA AND LITHUANIA
}

\author{
Ilona Reḳe ${ }^{1}$, Armands Celms $^{1}$, Mārtiṇš Reiniks² \\ ${ }^{1}$ Latvia University of Agriculture \\ ${ }^{2}$ Riga Technical University, Latvia \\ Ilona.Reke@gmail.com
}

\begin{abstract}
As European Union member states - Latvia and Lithuania have changed their national height systems from Baltic Normal Height System 1977 to European Vertical Reference System realizations. Performing practical Global Navigation Satellite System (GNSS) measurements and obtained data mathematical processing, there is a possibility to calculate point height difference between GNSS data and data of $1^{\text {st }}$ order levelling networks. The aim of the research is to gain insight for methodology development of geodetic point height testing using GNSS measurements. To achieve the goal following tasks are set: 1) perform GNSS measurements of first order levelling network in Latvia and Lithuania; 2) do data processing to get point ellipsoidal height and compare with the point normal height; 3) detect technically feasible accuracy of geoid model for precise height measurements with GNSS method within research area. Performing GNSS measurements at the same time in the territory of Latvia and Lithuania, the experience of mutual cross-border cooperation was accumulated. The results were adjusted with academic software package Bernese and were obtained point ellipsoidal and normal heights. The height measurement accuracy using GNSS method depends on geoid model accuracy and more precise results can be obtained increasing used geoid model accuracy to 1.5 to $2 \mathrm{~cm}$.
\end{abstract}

Key words: vertical network, GNSS, geoid model.

\section{Introduction}

Three Baltic states - Estonia, Latvia and Lithuania have good corporation in many fields, also in geodesy sector - in Baltic states was used united national height system - Baltic Normal Height System 1977 (BHS1977) (Celms, Helfrica, \& Kronbergs, 2007) and heights between states were connected in united geodetic network. Since $1^{\text {st }}$ December 2014 in Latvia as the European Union member state Cabinet of Ministers and state laws as a national height system finds the European Vertical Reference System realization in Latvia - Latvian Normal Height System 2000,5 (LHS-2000,5) (Celms, Bimane, \& Reke, 2014). Lithuania changed their national height system to European Vertical Reference System realization in Lithuania - Lithuanian height system LAS07 on January 1, 2016. Approximate difference between the old (BHS1977) and new height system (LAS07) in the middle of Lithuania is about $14 \mathrm{~cm}$.

Nowadays, the Global Navigation Satellite System (GNSS) offers more and more advantages. To gain insight into methodology development of geodetic point height testing using GNSS measurements, authors used GNSS method and did measurements of 13 first order levelling network points in the territory of Latvia, and 5 first order levelling network points in the territory of Lithuania were obtained. The global positioning as a method was chosen because of its simplicity - by using global positioning and calculating ellipsoidal coordinates, it is possible to see the height difference control in height system datum point and regional main geodetic points (Lazdans et al., 2009). On these points where direct GNSS observations are impossible to do, there is still a need for precise levelling works (Celms et al., 2013).

The levelling network is a national height system forming element. Levelling network ensures the realization of various functions in the national economy (Celms, Kronbergs, \& Cintina, 2013).

For precise GNSS measuring, it is necessary to have a precise quasigeoid model. Since $1^{\text {st }}$ December 2014 Latvian specialists have developed a new quasigeoid model from LV98 to LV'14 with $4 \mathrm{~cm}$ accuracies (Latvijas kvazigeoìda modelis, 2015). Lithuanian digital geoid model will be improved after completing the first and second order of geodetic vertical network. This will enable to derive normal height from ellipsoidal heights determined by GNSS and replace traditional levelling of lower orders (Krikštaponis et al., 2014).

The aim of the research is to gain insight for methodology development of geodetic point height testing using GNSS measurements. To achieve the goal, following tasks are set: 1) perform GNSS measurements of first order levelling network in Latvia and Lithuania; 2) do data processing to get point ellipsoidal height and compare with point normal height; 3) detect technically feasible accuracy of geoid model for precise height measurements with GNSS method within research area.

\section{Materials and Methods}

Establishment of Latvian National First Order Levelling Network began in 2000 and field measurements were finished in 2010 (Celms \& Kaminskis, 2005). Geodetic measurements 


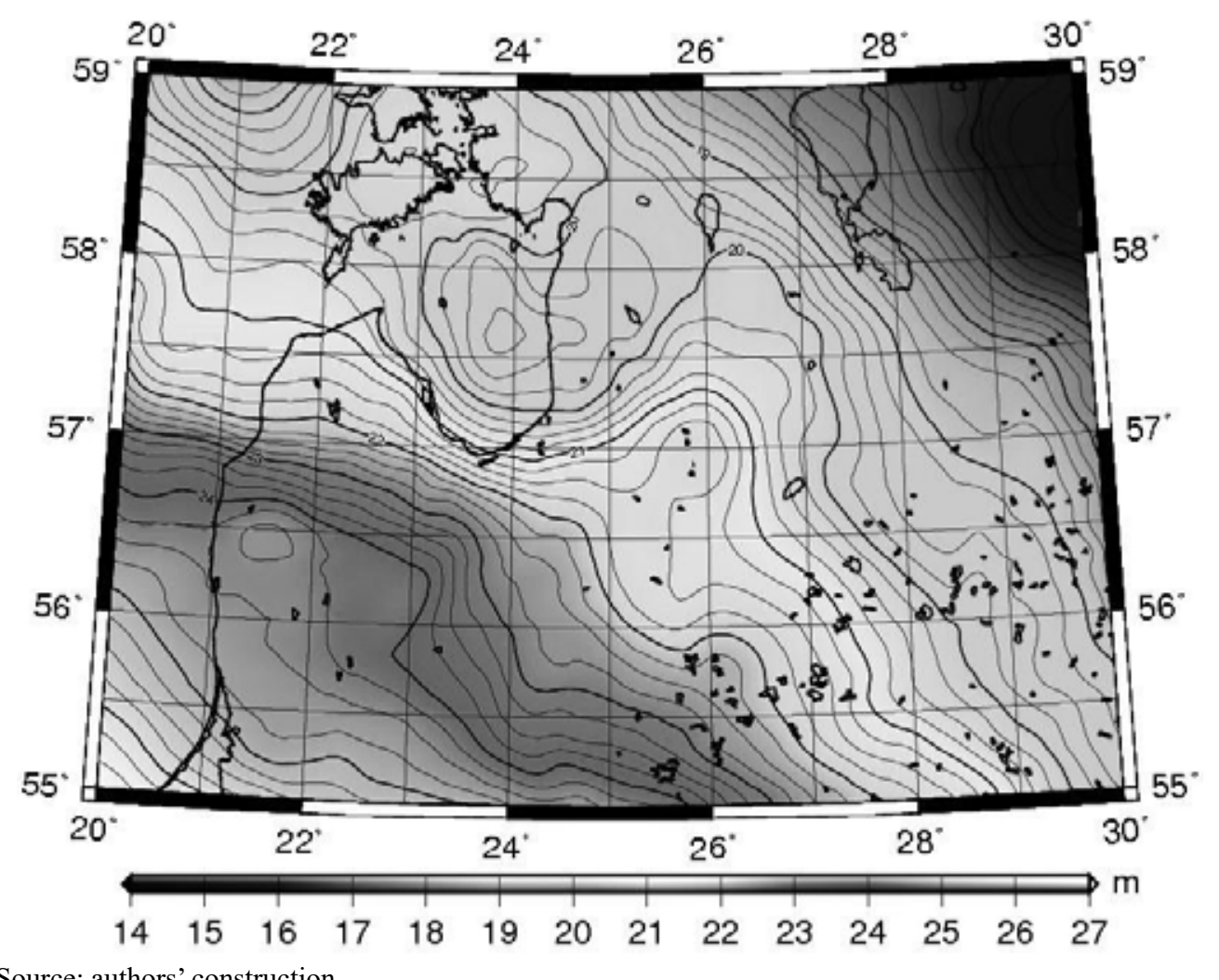

Source: authors' construction.

Figure 1. Geoid model LV98 for territory of Latvia and Lithuania.

were made by the specialists of the Latvian Land Service from 2000 to 2005 and Latvian Geospatial Information agency from 2006 to 2010. Geodetic and gravimetric observation data were used for the network establishment. The general requirement for not exceeding RMS error $0.5 \mathrm{~mm} \mathrm{~km}^{-1}$ of the measured height differences was followed in the course of establishment of the National First Order Levelling Network (Celms, Kronbergs, \& Cintina, 2012).

Lithuanian National First Order Network (NGVN) establishment was going on from 1998 to 2007. Contracting authority for network establishment was National Land Service under the Ministry of Agriculture. It consists of 5 loops of precise levelling lines (Aleksejenko et al., 2011).

Connection between Latvian and Lithuanian vertical networks is made in three places, so connecting lines construct the two first order levelling loops. The accuracy of Latvian and Lithuanian united levelling network in first iteration (standard deviation is $0.617 \mathrm{kgal} \times \mathrm{mm} \mathrm{km}^{-1}$ ) is at the same level as that of the vertical networks of the biggest part of other participating in UELN project countries (Aleksejenko et al., 2011). In 2008, Lithuania also created two border connection points with Poland, thus connecting Lithuanian vertical network to European vertical network (Krikstaponis \& Tumeliene, 2011). Now after national height systems' replacement from Baltic
Normal Height System 1977 to European Vertical Reference System realisations in Latvia and Lithuania, the height connection between Latvia and Lithuania has been lost (Celms, Reke, \& Ratkevics, 2015).

For height determination traditionally precise levelling was used and nowadays mostly for measurements and heights we also use GNSS as advanced instrument and new technology. There are many opportunities to do studies on heights and compatibility between selected geodetic points. Very suitable instrument for studies or research on geodetic consistency is homogenous quasi-geoid or geoid model over decided area. In our case, we found a suitable geoid model LV98 (Fig. 1.) for this purpose. In the future, we are planning to introduce also NKG2015 geoid for validation and verification of geodetic network (Latvijas kvazigeoìda modelis, 2015).

For the GNSS measurements first of all, there was the national geodetic network point inspection done. There were some points selected and then visited on site to detect the horizon above point for each point and possibility to use GNSS methods for its height determination, the point location conformity to point sketch. Also, global positioning real time measurements were done to detect the location of satellites above point. The requirement of open area is 20 degrees and for GNSS measurement PDOP 


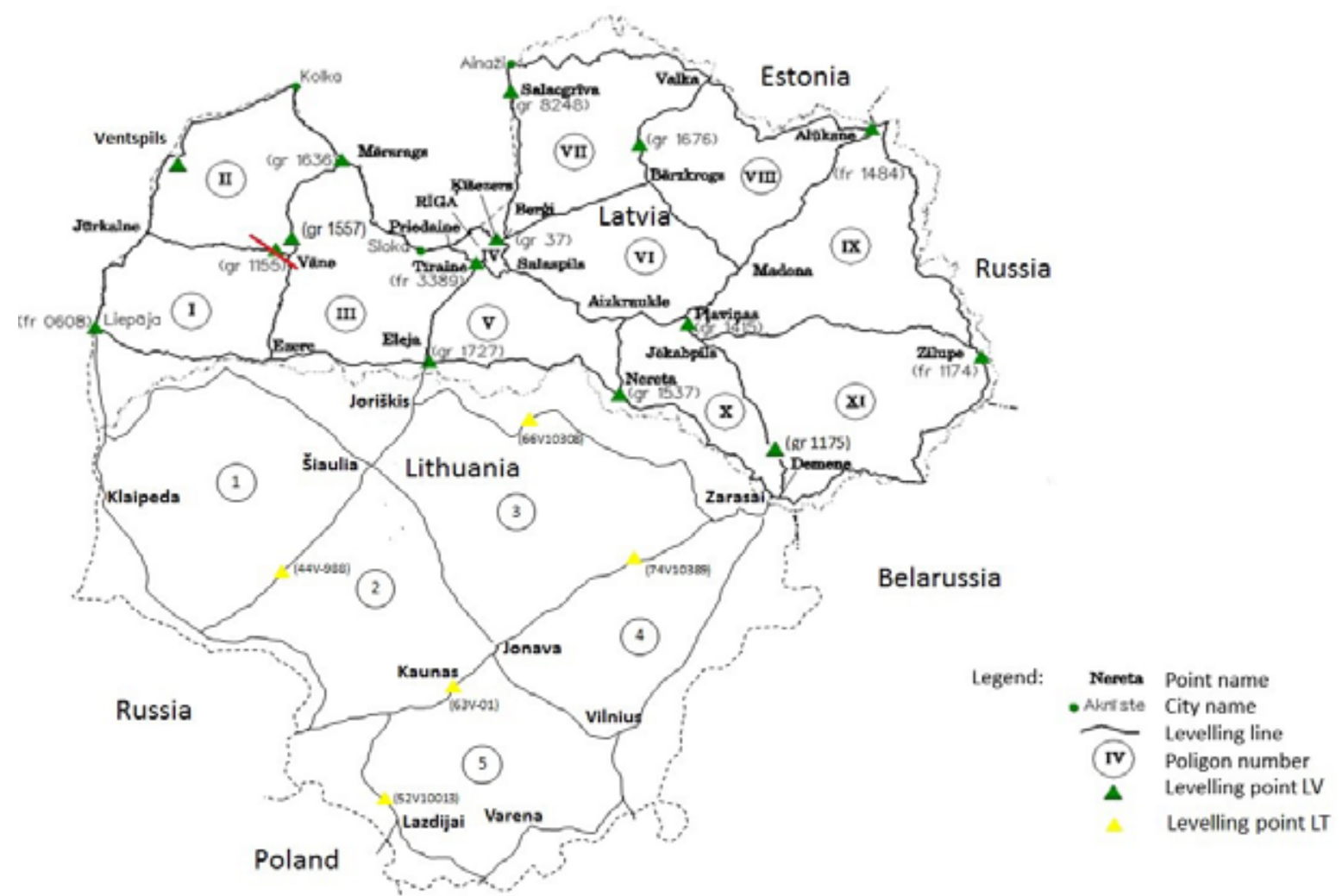

Source: authors' construction.

Figure 2. Performed GNSS measurements in $1^{\text {st }}$ class levelling network of Latvia and Lithuania.

should be at least 4 satellites. After inspection, there were thirteen $1{ }^{\text {st }}$ class levelling network points chosen, as an appropriate geodetic point for GNSS measurements - ground marks 1415, 1001, 37, 1155, $1537,1636,1676,1727,8248$ and fundamental marks 1484, 0608, 3389 and 1463. In Lithuania, following first order geodetic points were measured: ground marks 44V-988, 74V10308, 63V-01, 52V10013 and 74V10389 (Fig. 2).

In this project, specialists from Latvian University of Agriculture, Riga Technical University, Latvia University, Aleksandras Stulgiskis University, Kaunas Technical University and some private companies from Latvia were involved. The main idea was to perform GNSS measurements on all selected points at the same time and use global positioning in postprocessing mode providing avoidance from some errors.

In three years, 3 measurement sessions of Latvian first order levelling network $-14^{\text {th }}$ December 2012 , $22^{\text {th }}$ November 2013 and $27^{\text {th }}$ November 2014 were performed. On June 30, 2016 in the $4^{\text {th }}$ session experts from Lithuania were involved and at the same time 13 first order levelling points in Latvia and 5 first order levelling points in Lithuania (Fig. 2.) were measured.

In measuring sessions from 2012 - 2014, the GNSS measurement took 4 hours in the morning about 10 to 14 o'clock in Latvia Positioning System
Base Station (LatPOS) network. LatPOS is GNSS continuously operating the network of Latvia (Celms, Ratkevics, \& Rusins, 2014). On each point a GNSS receiver - Leica, Trimble, Topcon or GeoMax receiver was installed - and GNSS data were collected for 4 hours. In 2016, the duration of measurements was 5 hours in the early morning from about 6 to 11 o'clock in LatPOS network and Lithuania Positioning System Base Station (LitPOS) network.

For precise data processing and adjustment after measuring, there were collected data from 3 nearest LatPOS or LitPOS base stations. The data from GNSS receivers and LatPOS/LitPOS stations were used for data adjustment and point height determination (Reiniks, Lazdans, \& Ratkus, 2010).

GNSS collected data were processed and analysed using academic software package Bernese GNSS Software (Version 5.2). For data processing the following requirements were raised: blind angle 20 degrees form horizon, precise ephemerides, NGS antenna calibration models, closest vector selection and free network adjustment.

\section{Results and Discussion}

Adjusted results from performed GNSS measurements are listed in Table 1. Using academic software package Bernese GNSS, it is possible to obtain point ellipsoidal heights. 
Point ellipsoidal and normal heights of measured points

Table 1

\begin{tabular}{|c|c|c|c|}
\hline & Point name & Point ellipsoidal height, $\mathrm{m}$ & Point normal height, $\mathrm{m}$ \\
\hline \multirow{13}{*}{. } & 1001 & 155.138 & 138.649 \\
\hline & 1155 & 105.379 & 82.026 \\
\hline & 1415 & 100.050 & 76.842 \\
\hline & 1484 & 137.208 & 156.812 \\
\hline & 1537 & 104.972 & 80.458 \\
\hline & 1636 & 21.108 & 6.852 \\
\hline & 1676 & 84.170 & 58.531 \\
\hline & 1727 & 58.824 & 32.387 \\
\hline & 37 & 31.684 & 7.383 \\
\hline & 8248 & 19.581 & 4.722 \\
\hline & 0608 & 21.713 & 5.727 \\
\hline & 3389 & 34.360 & 12.474 \\
\hline & 1463 & 43.261 & 13.476 \\
\hline \multirow{5}{*}{ 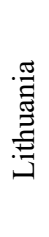 } & 44V-988 & 123.787 & 112.608 \\
\hline & 74V10389 & 153.496 & 125.565 \\
\hline & $63 \mathrm{~V}-01$ & 64.268 & 35.731 \\
\hline & 66V10308 & 45.611 & 34.447 \\
\hline & $52 \mathrm{~V} 10013$ & 158.414 & 127.085 \\
\hline
\end{tabular}

RMS errors of measured points

\begin{tabular}{|l|c|c|c|}
\hline \multicolumn{1}{|c|}{ Point name } & RMS error $\mathrm{N}, \mathrm{m}$ & RMS error E, $\mathrm{m}$ & RMS error U, $\mathrm{m}$ \\
\hline 1001 & 0.001 & 0.001 & 0.004 \\
\hline 1155 & 0.001 & 0.001 & 0.002 \\
\hline 1415 & 0.001 & 0.001 & 0.003 \\
\hline 1484 & 0.001 & 0.001 & 0.003 \\
\hline 1537 & 0.001 & 0.001 & 0.004 \\
\hline 1636 & 0.001 & 0.001 & 0.005 \\
\hline 1676 & 0.001 & 0.001 & 0.004 \\
\hline 1727 & 0.001 & 0.001 & 0.004 \\
\hline 37 & 0.001 & 0.002 & 0.003 \\
\hline 8248 & 0.001 & 0.001 & 0.004 \\
\hline 0608 & 0.000 & 0.000 & 0.001 \\
\hline 3389 & 0.000 & 0.000 & 0.001 \\
\hline 1463 & 0.000 & 0.000 & 0.001 \\
\hline $44 \mathrm{~V}-988$ & 0.002 & 0.002 & 0.006 \\
\hline $74 \mathrm{~V} 10389$ & 0.000 & 0.000 & 0.001 \\
\hline $63 \mathrm{~V}-01$ & 0.000 & 0.000 & 0.001 \\
\hline $66 \mathrm{~V} 10308$ & 0.000 & 0.000 & 0.001 \\
\hline $52 \mathrm{~V} 10013$ & 0.002 & 0.002 & 0.008 \\
\hline
\end{tabular}


Bernese is one of the most precise software programs and using GNSS measurements nowadays, it is possible to get height values with high accuracy. As seen in Table 1, ellipsoidal heights should be calculated to normal heights. Consequently, this study requires a further research.

Performed measurements have high accuracy which describes root mean square errors. The point evaluation of the North and East values is less than $2 \mathrm{~mm}$. Height component average value is approximately $3 \mathrm{~mm}$, and in some points it reaches 6 and $8 \mathrm{~mm}$. Mean error value for axis $\mathrm{N}$ and $\mathrm{E}$ is 0.001 $\mathrm{m}$, but measurement height component average error value is $0.003 \mathrm{~m}$. The normal height determination accuracy with GNSS method depends on used geoid model accuracy and more precise results can be obtained increasing geoid model accuracy up to 1.5 to $2 \mathrm{~cm}$ which is the aim-accuracy of new geoid model of Latvia - LV'14.

\section{Acknowledgements}

The research was supported by the project 'Strengthening Research Capacity in the Latvia University of Agriculture'.

\section{Conclusions}

It was possible to successfully organize GNSS measurement works thanks to previous preparation and critical situation analysis. Performing GNSS measurements at the same time in the territory of Latvia and Lithuania, the experience of mutual crossborder cooperation has been accumulated.

It is very significant to use advanced measuring technologies and verified data processing methodology for height determination using GNSS measurements.

In connection with geoid model significance to geodetic result data precision, it is desirable to perform GNSS measurements of I class levelling networks in Latvia, Lithuania and Estonia. This way it can verify and test geoid model on larger areas thereby getting certainty about geoid model precision. Accuracy of performed measurements describes RMS errors. Average error value for axis $\mathrm{N}$ and $\mathrm{E}$ is 0.001 $\mathrm{m}$, but measurement height component average error value is $0.003 \mathrm{~m}$. The height measurement accuracy using GNSS method depends on used geoid model accuracy, and more precise results can be obtained by increasing geoid model accuracy from 1.5 to $2 \mathrm{~cm}$.

\section{References}

1. Aleksejenko, I., Kaminskis, J., Sakne, J., Kalinka, M., Reiniks, M., Krikštaponis, B., Petroskevicius, P., Parseliunas, E.K., Viskontas, P., Kalanaite, A., \& Urbanas, S. (2011). Levelling network Connection Between Latvia and Lithuania. In Enivronmental Engineering, 19 - 20 May 2011 (pp. 1269 - 1278). Vilnius, Lithuania: Vilnius Gediminas Technical University.

2. Celms, A., Bimane, I., \& Reke, I. (2014). European Vertical Reference System in Baltic Countries. Baltic Surveying. 1 (8), 49 - 55. ISSN 2255-999X.

3. Celms, A., Helfrica, B., \& Kronbergs, M. (2007). Резултаты нивелирования I класса в западнойчасти Латвии ( $1^{\text {st }}$ class levelling works in west part of Latvia). Baltic Surveying. 1, 14 - 18. (in Russian).

4. Celms, A., \& Kaminskis, J. (2005). Levelling results of first order line Kolka - Rucava. In Baltic Surveying '05, 12 - 13 May 2005 (pp. 165 - 170). Jelgava, Latvia: Latvia University of Agriculture.

5. Celms, A., Kronbergs, M., \& Cintina, V. (2012). Accuracy Estimation of the Latvia First Order levelling Network. GEOFORUM.1, $44-47$.

6. Celms, A., Kronbergs, M., Cintina, V., \& Baumane, V. (2013). Precision of Latvia Levelling Network Nodal Point Height. CIVIL ENGINEERING. 4, 310 - 317.

7. Celms, A., Ratkevics, A., \& Rusins, J. (2014). Research of National Geodetic Network Elevations in Eastern Part of Latvia. Baltic Surveying. 1, 84 - 91.

8. Celms, A., Reke, I., \& Ratkevics, A. (2015). European Vertical Reference System Influence in Latvia. In 2nd International Conference Innovative Materials, Structures and Technologies, 30 September -2 October 2015 (pp. 30 - 37). Riga: Riga Technical University.

9. Krikštaponis, B., Paršeliūnas, E.K., Viskontas, P., Neseckas, A., Zigmantiene, E., Kolosovskis, R., Musteikis, A., Tumeliene, E., Birvydiene, R., \& Petroškevičius, P. (2014). Designing issues of the geodetic vertical reference network of Lithuania. In Enivronmental Engineering, 22 - 23 May 2014 (pp. 1 - 10). Vilnius, Lithuania: Vilnius Gediminas Technical University.

10. Krikštaponis, B., \& Tumeliene, E. (2011). Development of Lithuanian National Geodetic Vertical First Order Network. In Enivronmental Engineering, 19 - 20 May 2011 (pp. 1362 - 1369). Vilnius, Lithuania: Vilnius Gediminas Technical University.

11. Latvijas kvaziǵgeōda modelis (Latvian quasigeoid model) (2015). Retrieved 11 March, 2015, from: http:// map.lgia.gov.lv/index.php?lang=0\&cPath=2\&txt $\mathrm{id}=130$. (in Latvian).

12. Lazdans, J., Aleksejenko, I., Kaminskis, J., Celms, A., Kalinka, M., Klive, J., \& Reiniks, M. (2009). Aktualitāte Latvijas sasaistē ar Eiropas augstumu sistēmu (Current Events Latvia Connecting with 
European Height System). In Latvia University Scientific conference No.67, 12 February 2009. Riga: Latvia University. (in Latvian).

13. Reiniks, M., Lazdans, J., \& Ratkus, B. (2010). Valsts augstuma izejas līmeņa noteikšana (Determination of state height datum level). Riga Technical University scientific articles.Nr.7, 7 - 13. lpp. (in Latvian). 